\title{
Correlations between Corporate Climate Change Management and Financial Performance: A Case Study of Japanese Automobile Manufacturers
}

\author{
Miyako Enokibori ${ }^{1}$, Ryuji Matsuhashi ${ }^{2}$, Yoshikuni Yoshida ${ }^{1}$ \\ ${ }^{1}$ Department of Environment Systems, Graduate School of Frontier Sciences, The University of Tokyo, Kashiwa, Japan; ${ }^{2}$ Department \\ of Electrical Engineering and Information Systems, Graduate School of Engineering, The University of Tokyo, Tokyo, Japan. \\ Email: enokibori@globalenv.k.u-tokyo.ac.jp
}

Received September $13^{\text {th }}, 2013$; revised October $12^{\text {th }}, 2013$; accepted October $20^{\text {th }}, 2013$

Copyright (C) 2013 Miyako Enokibori et al. This is an open access article distributed under the Creative Commons Attribution License, which permits unrestricted use, distribution, and reproduction in any medium, provided the original work is properly cited.

\begin{abstract}
Using data from a survey, we examined actions taken by large corporations based in three countries to combat climate change and related these actions to the corporations' financial performance. We analyzed the correlation between financial performance and climate change management performance to determine the extent that climate change management activities are a net cost or a net benefit to companies. We found that corporate climate change management performance is generally positively correlated with financial performance, but that the relationship differs among countries due to national-level external factors. A case study of Japanese automobile manufacturing companies showed that sales of a company's fuel-efficient cars, reflecting consumers' awareness of climate change, are associated with higher valuation by financial markets.
\end{abstract}

Keywords: Corporate Climate Change Management; Financial Analysis; Correlation Analysis; Automobile Manufacturer; Vehicle Fuel Efficiency

\section{Introduction}

Climate change has been recognized as a serious issue for a considerable time, and is addressed in various ways in different industrial sectors. Companies may reduce greenhouse gas emissions resulting from their operations and products, either voluntarily or by mandate. Initially it was generally believed that emissions reduction would be a high net cost, and have little "bottom-line" benefit to companies. In recent years, however, consumers have increased purchases of energy-efficient goods and services that allow them to reduce their carbon footprint. The increasing demand for this kind of product can now be shown to represent the potential for higher profits. In addition, since the fall of Lehman Brothers in 2008, institutional investors now evaluate such non-financial corporate information as environmental, social, and governance (ESG) factors in addition to traditional financial information. Companies that actively address climate change may therefore be favorably regarded by some investors.

The relationship between environmental activities and profits may not be apparent to companies in the absence of relevant data and analysis. Previous studies showed positive relationships between corporate motivation for environmental action and corporate financial indicators or market valuation. Takeda and Tomozawa investigated stock price reactions to the environmental management rankings issued by Nihon Keizai Shimbun (a Japanese financial newspaper). Using a standard event study methodology they found that market reaction changed between 2001 and 2002, when the Japanese government demonstrated commitment to environmental policies by establishing a Ministry of the Environment, enacting environmental legislation, and signing the Kyoto Protocol [1]. Kuribayashi and Kameyama concluded that environmental management activities influence the financial management and valuation of equipment manufacturing companies [2]. Whereas these studies considered the general environmental activities of corporations, we have focused on corporate climate change management in this research. We constructed an index that summarizes corporate climate change management performance by us- 
ing survey data and estimated the relationships between this index and financial performance. We present a case study of Japanese auto manufacturers in order to estimate the influence of carbon-conscious consumers on corporate financial performance.

\section{Evaluation of Corporate Climate Change Management Performance and Financial Performance}

\subsection{Corporate Climate Change Management Performance Index}

We selected seven dimensions of corporate climate change management performance (Tables 1-7) based on the output of a working group set up by the Japanese Ministry of Economy, Trade and Industry to develop evaluation methods for corporate environmental management. We used raw data on corporate climate change management from a questionnaire survey of large corporations conducted by CDP since 2003 on behalf of institutional investors (CDP signatories). The 519 companies targeted included 108 corporations based in Japan, 149 based in the United States, and 99 based in the United Kingdom.

Table 1. Corporate climate change performance index: governance and strategy.

\begin{tabular}{ccc}
\hline Topic & Detail & $\begin{array}{c}\text { Weighting } \\
\text { factor }\end{array}$ \\
\hline $\begin{array}{c}\text { Governance } \\
\text { and strategy }\end{array}$ & $\begin{array}{c}\text { Climate change strategy } \\
\text { Responsibility for climate change } \\
\text { within the company }\end{array}$ & 0.37 \\
& $\begin{array}{c}\text { Mechanism to review the company's } \\
\text { progress and status regarding climate change }\end{array}$ & 0.27 \\
\hline
\end{tabular}

Table 2. Corporate climate change performance index: risks.

\begin{tabular}{|c|c|c|c|}
\hline Topic & \multicolumn{2}{|c|}{ Detail } & $\begin{array}{c}\text { Weighting } \\
\text { factor }\end{array}$ \\
\hline \multirow{10}{*}{ Risks } & \multicolumn{2}{|c|}{ Process to identify climate change risks } & 0.07 \\
\hline & \multirow{3}{*}{ Regulatory risks } & Risk description & 0.09 \\
\hline & & Impact of the risk & 0.10 \\
\hline & & Risk management & 0.11 \\
\hline & \multirow{3}{*}{ Physical risks } & Risk description & 0.10 \\
\hline & & Impact of the risk & 0.11 \\
\hline & & Risk management & 0.11 \\
\hline & \multirow{3}{*}{ Other risks } & Risk description & 0.10 \\
\hline & & Impact of the risk & 0.11 \\
\hline & & Risk management & 0.11 \\
\hline
\end{tabular}

Table 3. Corporate climate change performance index: opportunities.

\begin{tabular}{|c|c|c|c|}
\hline Topic & & Detail & $\begin{array}{l}\text { Weighting } \\
\text { factor }\end{array}$ \\
\hline \multirow{10}{*}{ Opportunities } & \multicolumn{2}{|c|}{$\begin{array}{l}\text { Process to identify climate } \\
\text { change opportunities }\end{array}$} & 0.07 \\
\hline & \multirow{3}{*}{$\begin{array}{l}\text { Regulatory } \\
\text { opportunities }\end{array}$} & Opportunity description & 0.09 \\
\hline & & Impact of the opportunity & 0.11 \\
\hline & & Opportunity management & 0.11 \\
\hline & \multirow{3}{*}{$\begin{array}{c}\text { Physical } \\
\text { opportunities }\end{array}$} & Opportunity description & 0.09 \\
\hline & & Impact of the opportunity & 0.11 \\
\hline & & Opportunity management & 0.10 \\
\hline & \multirow{3}{*}{$\begin{array}{c}\text { Other } \\
\text { opportunities }\end{array}$} & Opportunity description & 0.10 \\
\hline & & Impact of the opportunity & 0.11 \\
\hline & & Opportunity management & 0.11 \\
\hline
\end{tabular}

Table 4. Corporate climate change performance index: Emissions accounting.

\begin{tabular}{|c|c|c|c|}
\hline Topic & \multicolumn{2}{|c|}{ Detail } & $\begin{array}{l}\text { Weighting } \\
\text { factor }\end{array}$ \\
\hline \multirow{10}{*}{$\begin{array}{l}\text { Emissions } \\
\text { accounting }\end{array}$} & \multirow{2}{*}{ Scope 1 emissions } & Domestic & 0.11 \\
\hline & & Abroad & 0.10 \\
\hline & \multirow{2}{*}{ Scope 2 emissions } & Domestic & 0.11 \\
\hline & & Abroad & 0.11 \\
\hline & \multicolumn{2}{|c|}{ Scope 3 emissions } & 0.10 \\
\hline & \multirow{3}{*}{ Emission intensity } & Financial intensity & 0.10 \\
\hline & & Physical intensity & 0.10 \\
\hline & & Scope 1 emissions & 0.09 \\
\hline & \multirow[t]{2}{*}{ External verification } & Scope 2 emissions & 0.09 \\
\hline & & Scope 3 emissions & 0.08 \\
\hline
\end{tabular}

Table 5. Corporate climate change performance index: emissions reduction target.

\begin{tabular}{|c|c|c|c|}
\hline Topic & & Detail & $\begin{array}{l}\text { Weighting } \\
\text { factor }\end{array}$ \\
\hline \multirow{3}{*}{$\begin{array}{l}\text { Emissions } \\
\text { reduction target }\end{array}$} & \multirow{3}{*}{$\begin{array}{l}\text { Emissions } \\
\text { reduction target }\end{array}$} & Scope 1 emissions & 0.36 \\
\hline & & Scope 2 emissions & 0.36 \\
\hline & & Scope 3 emissions & 0.27 \\
\hline
\end{tabular}

Each selected topic comprises several factors that we weighted (using expert consensus) to more highly value a company that strongly encourages climate change mitigation and adaptation. To estimate the total weighting of each topic we calculated weighting factors by principal component analysis to account for the variability be- 
Table 6. Climate change performance index: emissions reduction activity.

\begin{tabular}{ccc}
\hline Topic & Detail & $\begin{array}{c}\text { Weighting } \\
\text { factor }\end{array}$ \\
\hline $\begin{array}{c}\text { Emissions } \\
\text { reduction activity }\end{array}$ & $\begin{array}{c}\text { Emissions reduction activities } \\
\text { of goods and services } \\
\text { Emissions offsetting }\end{array}$ & 0.37 \\
& 0.36 & 0.27 \\
\hline
\end{tabular}

Table 7. Corporate climate change performance index: communication.

\begin{tabular}{ccc}
\hline Topic & Detail & $\begin{array}{c}\text { Weighting } \\
\text { factor }\end{array}$ \\
\hline \multirow{2}{*}{ Communication } & $\begin{array}{c}\text { Disclosure in annual report } \\
\text { Disclosure in corporate social } \\
\text { responsibility or environmental report } \\
\text { Engagement with policy makers }\end{array}$ & 0.34 \\
\hline
\end{tabular}

tween these factors.

The selected topics were 1) governance and strategy, 2) risks, 3) opportunities, 4) emissions accounting, 5) emissions reduction target, 6) emissions reduction activity, and 7) communication. Governance and strategy 1) includes the factors of climate change strategy, responsbility for climate change within the company, and mechanisms for reviewing status and progress on climate change (Table 1). A corporate business strategy that was directly related to climate change mitigation or adaptation received a high numerical rating and additional points if the strategy was likely to achieve significant emissions reductions. A company received points for the responsibility factor if it managed climate change issues on a company-wide level, by a board committee, a specific designated department, or by the CEO or other senior executive. Similarly, an established review mechanism for climate change management, progress, and status received points. After rating the three items (strategy, responsibility, and mechanism) for all samples, we performed principal component analysis. In the analysis we used a correlation coefficient matrix, calculated eigenvalues corresponding to the contribution ratio and eigenvectors for each eigenvalue, and derived principal component scores for each eigenvector. In the case of these three items, the first principal component score was considered to represent the relative strength of the corporation's climate change strategy and governance of its implementation. The eigenvector for the first principal component was used as the weighting factor for governance and strategy.

Tables 2 and $\mathbf{3}$ show the various factors considered in the identification of climate change risks and opportunities, with subcategories of regulatory, physical, and other. We used survey data on corporate processes for assessing risks and opportunities, the frequency and the responsbility for them, and related factors to evaluate how well a company recognizes risks and opportunities, estimates their impact, and tries to manage them. Even if a company faces serious risks, they are rated highly if they recognize the risks and the impact and introduce appropriate risk management. The same analytical method as described above was used to obtain the first principal component, which represents the relative degree that a company tries to assess and manage risks and opportunities.

An emissions accounting score (Table 4) was derived from available survey data on monitoring Scope 1, 2, and 3 emissions and emissions intensities, and whether each is verified or assured by a third party. The actual values of emissions amounts and intensities were not considered relevant; instead, we considered simply whether they were assessed by timely and reliable methods. Separate ratings were given for domestic and foreign corporate operations.

Emissions reduction target (Table 5) was evaluated by whether a company sets a target for Scope 1, 2 and 3 emissions.

Emissions reduction activity (Table 6) scores whether a company introduces emission reduction activities for Scope 1, 2 and 3 emissions, whether customers can reduce their own emissions by using the company's goods and services, and whether a company originates or purchases offsetting carbon credits.

The communication component of the index (Table 7) represents corporate disclosure and engagement with policymakers. Points were given if a company discloses their climate change information such as reduction targets or number of emissions in their annual report or in some other voluntary report, such as a corporate social responsibility report. A company also was given points if it engages with policy makers on climate change taxation, regulation or carbon trading through direct discussion or participation in national committees.

\subsection{Corporate Financial Performance}

We analyzed corporate profitability, growth potential, and the enterprise value (EV) of companies with reference to their financial statements and share prices. As indicators of profitability we used the return on turnover, return on equity, return on assets, and return on investment. We used sales growth rate and the profit growth rate as indicators of growth potential.

\section{Analysis of Correlation between Corporate Climate Change Management and Financial Performance}

We analyzed the correlation between corporate climate 
change management and financial performance using 2010 data. We found no significant correlations when we analyzed all 519 targeted global companies together. Average standardized scores for climate change management performance criteria vary widely between the three countries (Japan, the United States, and the United Kingdom) as shown in Figure 1. The individual topic or dimension scores for corporations were quite homogeneous within countries but there were large differences between countries for most of the topics. For example, Japanese companies' score on emissions accounting is very low because the emissions trade scheme is not nationally regulated in Japan, reducing the need for external verification/assurance of emissions by companies. When results were analyzed for the three countries separately, correlations at the $5 \%$ significance level were found between corporate climate change management and financial performance, as shown in Figures 2-4.

\subsection{Result for Japanese Companies}

For the 108 Japanese companies, positive correlations were found between emissions accounting and profitability, and between emissions reduction target and profitability. The correlation factor (CF) between the return on turnover and emissions accounting was 0.22 , the CF between return on assets and emissions accounting was 0.21 , the CF between return on assets and emissions reduction targeting was 0.26 , and the CF between return on investment and emissions reduction target was 0.28 . Also, the enterprise value (EV) was positively correlated with governance and strategy with a CF of 0.22 .

These results imply that climate change management is related to efficient financial management of Japanese corporations and that actively setting emissions reduction targets may have a favorable impact on profitability. The positive correlations between emissions accounting and profitability, and between emissions reduction targeting and profitability both suggest that Japanese companies tend to make capital investments that aim for emissions reduction as well as high profits.

\subsection{Result for US Companies}

For the 149 US companies, there were both positive and negative significant correlations between climate change management and financial performance. The $\mathrm{CF}$ between return on turnover and opportunities was -0.22 , and the $\mathrm{CF}$ between return on assets and emissions reduction activity was -0.24 . These results imply that climate change opportunities do not lead to efficient use of assets in US companies. On the other hand, we found positive correlations between the EV and climate change performance. The $\mathrm{CF}$ between EV and governance and strategy was 0.28 , the CF between the EV and emissions reduction activity was 0.22 , and the CF between the EV and communication was 0.24 . The positive correlations suggest that the companies that prioritize socially responsible investment (SRI) by focusing on internal governance and external communication also aim to maximize the company's market value.

\subsection{Result for UK Companies}

For the 99 UK companies, positive correlations between climate change management and EV were comparatively high. The CF between the EV and governance and strategy was 0.22 , the CF between EV and opportunities was 0.35 and the $\mathrm{CF}$ between the $\mathrm{EV}$ and communication was 0.25 . As with the US companies, climate change man-

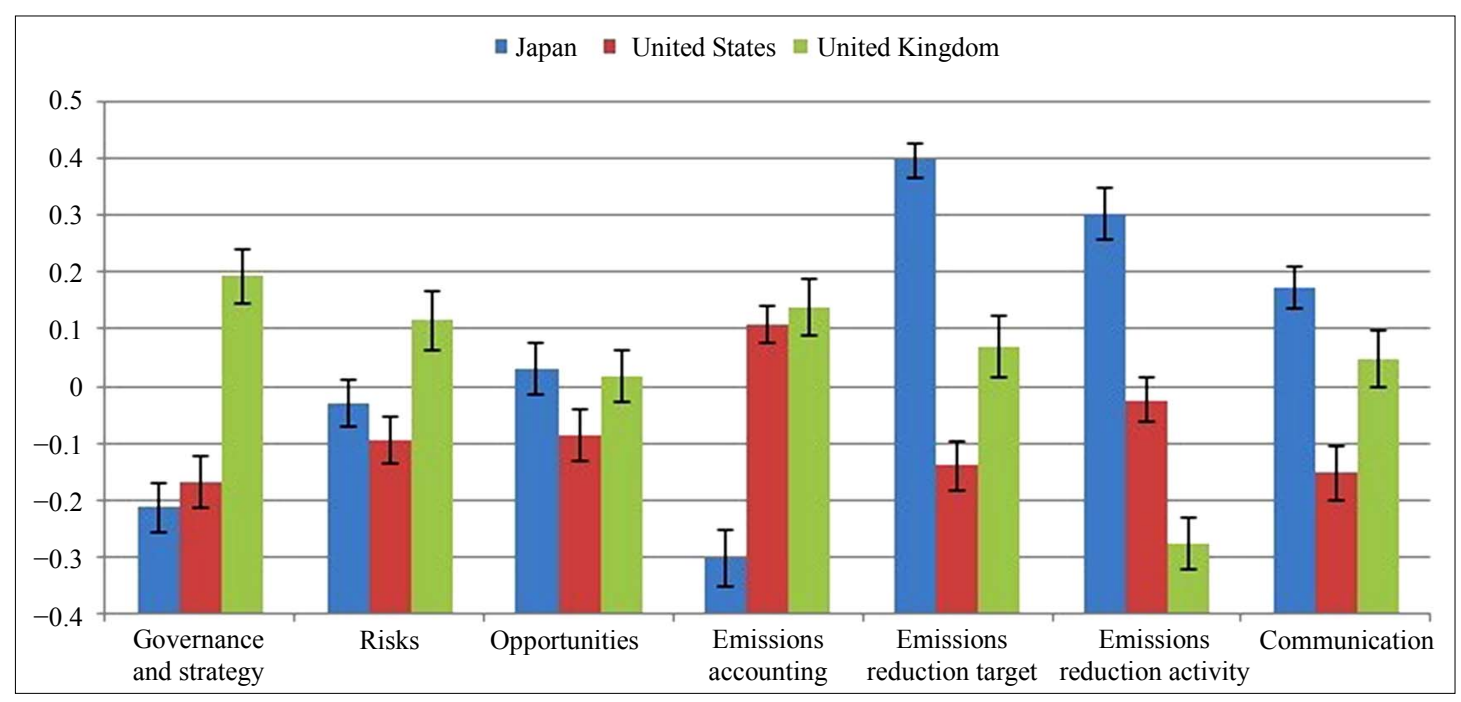

Figure 1. Average standardized score for corporate climate change management performance by topic and country. 


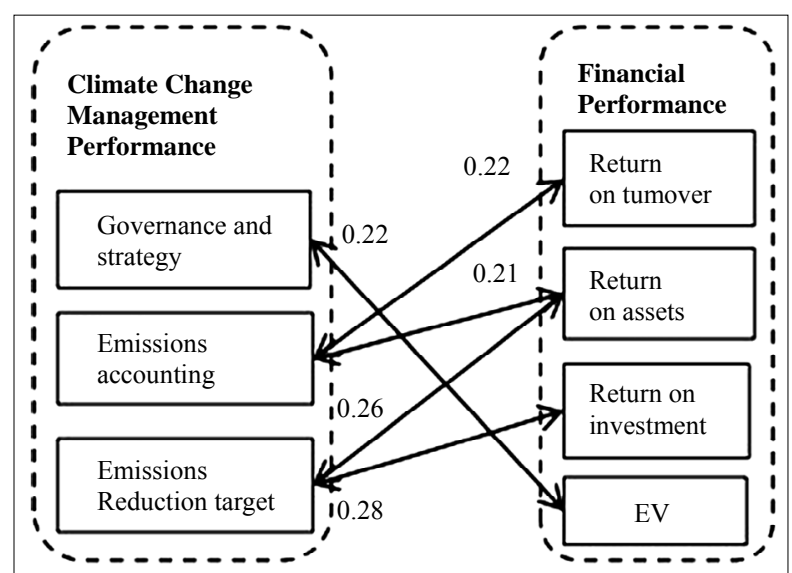

Figure 2. Correlation between corporate climate change management and financial performance for 108 Japanese companies.

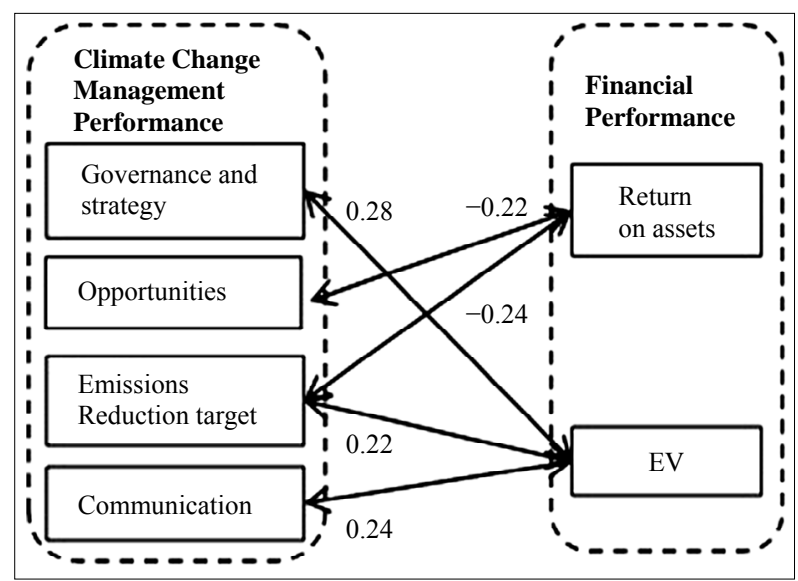

Figure 3. Correlation between corporate climate change management and financial performance for 149 US companies.

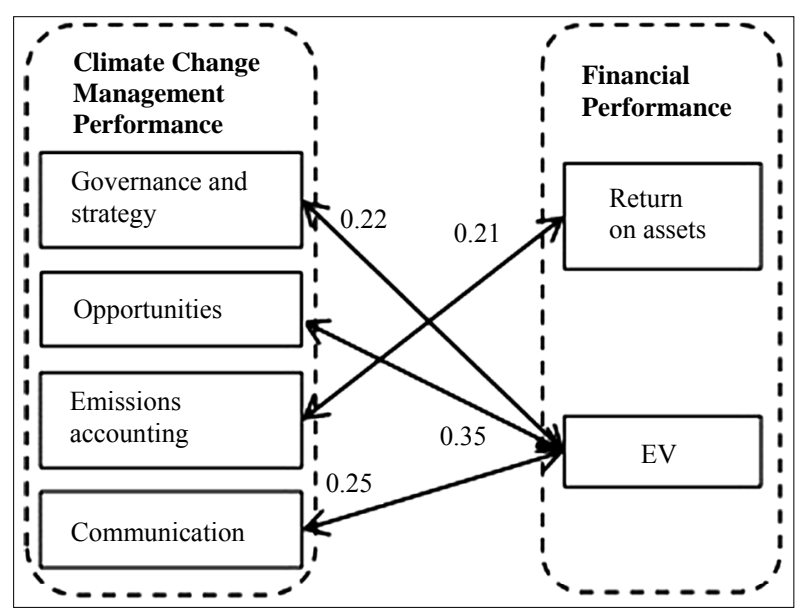

Figure 4. Correlation between corporate climate change management and financial performance for 99 UK companies. agement in the UK appears to correlate with valuation in the financial market, generally reflecting the opinion of investors. Unlike the US companies, the positive correlation between the EV and opportunities suggests an environment exists in the UK that encourages companies to act on opportunities for climate change management.

\subsection{Conclusion for the Correlation Analysis}

The correlation analyses above show that the climate change management performance is related to financial performance, but in ways that depend on each country's business culture. The results indicate that better management of climate change issues can enhance corporate financial performance and attract investors.

\section{Case Study: Japanese Automobile Manufactures}

Corporations are evaluated not only by investors through financial and non-financial information but also by customers through their products and/or services. To learn how customer choice affects corporate financial performance we conducted a case study targeting Japanese automobile manufacturers. According to a survey by Japan Automobile Manufacturer Association, after price and vehicle operation, customers focus on environmental design more than vehicle body design when buying a car [3]. We performed this study to confirm whether automobile manufacturers that sell more fuel-efficient vehicles gain a financial advantage situation and score higher on climate change management.

\section{Methodology}

We selected six Japanese automobile manufacturers for the sample: Toyota Motor, Nissan Motor, Honda Motor, Mazda Motor, Mitsubishi Motor and Fuji Heavy Industries. Only standard-sized and compact passenger vehicles sold in Japan were considered, with vehicle fuel efficiency obtained from published data (based on the Japanese 10-15 test mode), sales volume for standardsized vehicles obtained from Automobile Inspection \& Registration Information Association data and sales of compact vehicles from the Japan Mini Vehicles Association (Daihatsu data are consolidated with Toyota data, and Suzuki Motor is excluded because of its high ratio of compact to standard-sized vehicles sold).

The average of vehicle fuel efficiency for each manufacturer is defined by Equation (1). A higher value results when more fuel-efficient vehicles are sold, and is assumed to reflect customers' environmental awareness. The trend of increased average fuel efficiency over a tenyear period is clear from Figure 5. 


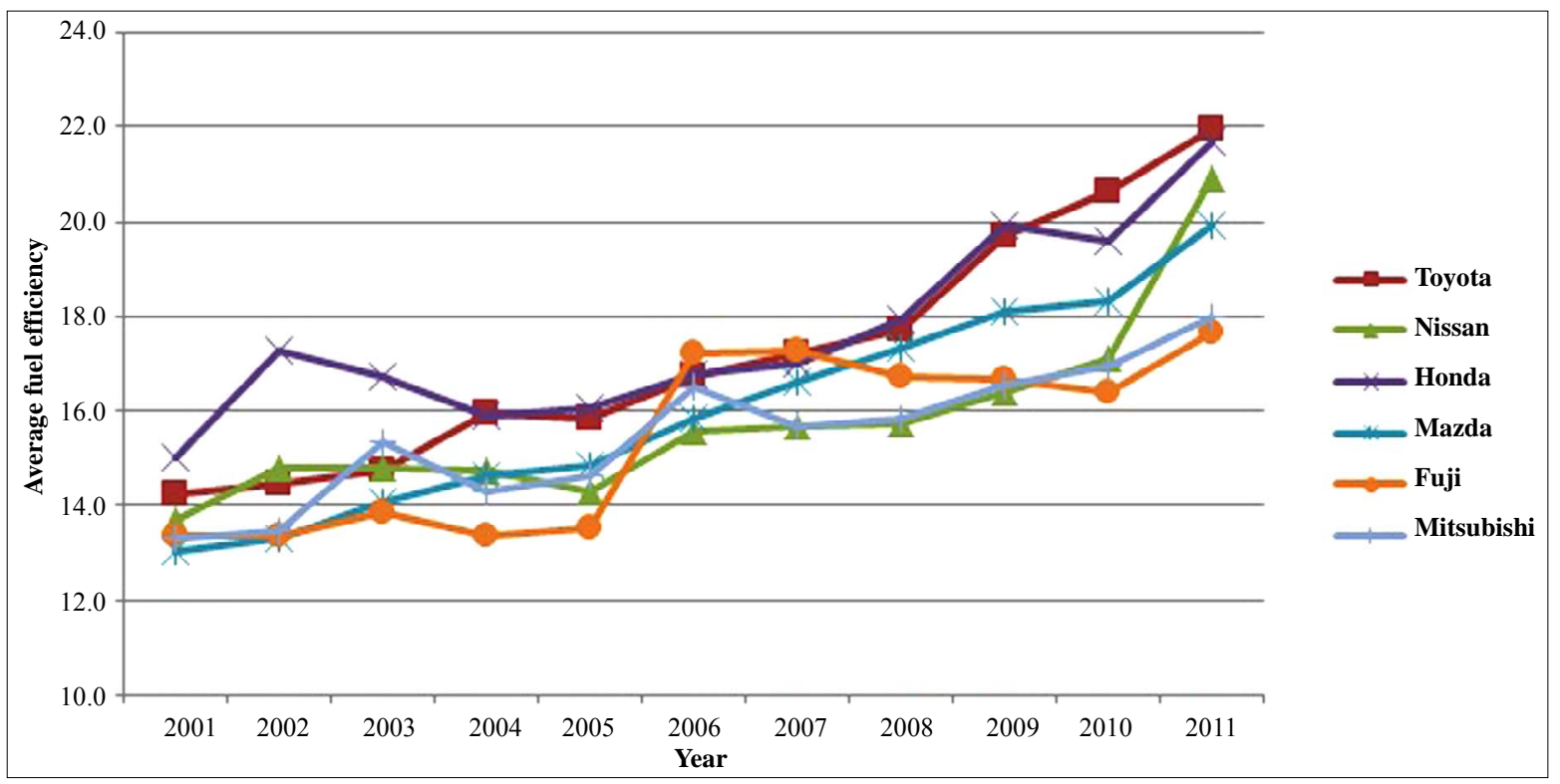

Figure 5. Average fuel efficiency of vehicles sold by each manufacturer.

$$
E_{Q, \text { ave }}=\sum \frac{E_{Q, i} \times N_{Q, i}}{N_{Q, a l l}}
$$

$E_{Q, a v e}:$ Average fuel efficiency of vehicles sold by manufacturer Q;

$E_{Q, i}:$ Fuel efficiency of vehicle $i$

$N_{Q, i}:$ Number of vehicle $i$ sold.

We then analyzed correlations between the manufacturers' average vehicle fuel economy and financial factors including EV and the stock ownership ratio of investors, and also with climate change management performance as described here. Regarding the stock ownership ratio of investors, we distinguished between Japanese institutional investors, foreign institutional investors, and CDP signatories to account for different investing environments. Institutional investors in countries other than Japan are more interested in ESG, while in Japan there is low awareness of socially responsible investment and public discussion of ESG has only started recently. CDP signatories are considered likely to be most concerned with corporate climate change management.

\section{Result}

As seen in Figure 6, there were positive correlations between corporate vehicle fuel efficiency and financial performance, and these generally increased rapidly over recent years. The average of corporate vehicle fuel efficiency was correlated with the natural log of EV. The increased correlation since 2008 suggests the growing importance placed by investors on companies' success in the fuel-efficient market segment. Similarly, the average fuel efficiency is correlated with the stock ownership

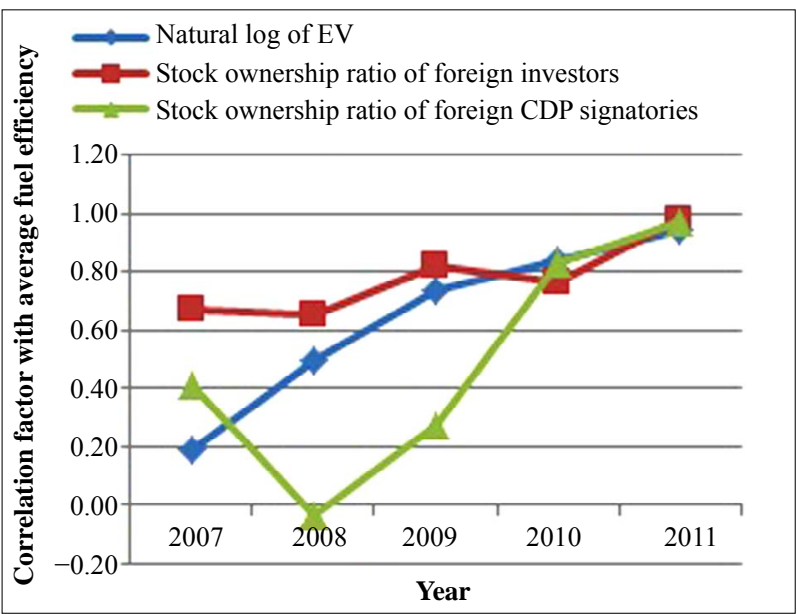

Figure 6. Correlation factor with average corporate fuel efficiency.

ratio of the foreign institutional investors.

In addition, the average corporate vehicle fuel economy was correlated with corporate climate change risk and opportunity assessment at a statistically significant level in 2011. This result suggests that vehicle manufacturers realize that responsiveness to customer demand for environmental design is a business opportunity while failure to respond it is considered a risk. Tables 8 and $\mathbf{9}$ show the correlations between the factors in 2010 and 2011.

\section{Conclusions}

Using data from a survey of 519 corporations, we found positive correlations between an original index of corpo- 
A Case Study of Japanese Automobile Manufacturers

Table 8. Correlation factors in 2010.

\begin{tabular}{|c|c|c|c|c|c|c|c|c|}
\hline & $\begin{array}{l}\text { Average of } \\
\text { fuel efficiency }\end{array}$ & $\ln (\mathrm{EV})$ & $\begin{array}{l}\text { Stock ownership } \\
\text { ratio of Japanese } \\
\text { investors }\end{array}$ & $\begin{array}{l}\text { Stock ownership } \\
\text { ratio of foreign } \\
\text { investors }\end{array}$ & $\begin{array}{l}\text { Stock ownership } \\
\text { ratio of Japanese } \\
\text { CDP signatories }\end{array}$ & $\begin{array}{l}\text { Stock ownership } \\
\text { ratio of foreign } \\
\text { CDP signatories }\end{array}$ & Risks & Opportunities \\
\hline Average of fuel efficiency & 1.00 & & & & & & & \\
\hline $\ln (E V)$ & *0.94 & 1.00 & & & & & & \\
\hline $\begin{array}{l}\text { Stock ownership ratio of } \\
\text { Japanese investors }\end{array}$ & 0.33 & 0.43 & 1.00 & & & & & \\
\hline $\begin{array}{l}\text { Stock ownership ratio of } \\
\text { foreign investors }\end{array}$ & ${ }^{*} 0.98$ & ${ }^{*} 0.94$ & 0.49 & 1.00 & & & & \\
\hline $\begin{array}{l}\text { Stock ownership ratio of } \\
\text { Japanese CDP signatories }\end{array}$ & -0.26 & -0.23 & 0.74 & -0.10 & 1.00 & & & \\
\hline $\begin{array}{l}\text { Stock ownership ratio of } \\
\text { foreign CDP signatories }\end{array}$ & *0.97 & ${ }^{*} 0.87$ & 0.39 & ${ }^{*} 0.97$ & -0.19 & 1.00 & & \\
\hline Risks & *0.84 & 0.62 & 0.28 & ${ }^{*} 0.84$ & -0.06 & ${ }^{*} 0.90$ & 1.00 & \\
\hline Opportunities & *0.89 & 0.74 & 0.49 & ${ }^{*} 0.92$ & 0.11 & ${ }^{*} 0.90$ & *0.94 & 1.00 \\
\hline
\end{tabular}

*Significant at $5 \%$ level.

Table 9. Correlation factors in 2011.

\begin{tabular}{|c|c|c|c|c|c|c|c|c|}
\hline & $\begin{array}{l}\text { Average of fuel } \\
\text { efficiency }\end{array}$ & $\ln (\mathrm{EV})$ & $\begin{array}{l}\text { Stock ownership } \\
\text { ratio of Japanese } \\
\text { investors }\end{array}$ & $\begin{array}{l}\text { Stock ownership } \\
\text { ratio of foreign } \\
\text { investors }\end{array}$ & $\begin{array}{l}\text { Stock ownership } \\
\text { ratio of Japanese } \\
\text { CDP signatories }\end{array}$ & $\begin{array}{l}\text { Stock ownership } \\
\text { ratio of foreign } \\
\text { CDP signatories }\end{array}$ & Risks & Opportunities \\
\hline Average of fuel efficiency & 1.00 & & & & & & & \\
\hline $\ln (\mathrm{EV})$ & * 0.83 & 1.00 & & & & & & \\
\hline $\begin{array}{l}\text { Stock ownership ratio of } \\
\text { Japanese investors }\end{array}$ & 0.56 & 0.34 & 1.00 & & & & & \\
\hline $\begin{array}{l}\text { Stock ownership ratio of } \\
\text { foreign investors }\end{array}$ & 0.76 & 0.79 & 0.56 & 1.00 & & & & \\
\hline $\begin{array}{l}\text { Stock ownership ratio of } \\
\text { Japanese CDP signatories }\end{array}$ & 0.27 & 0.02 & 0.93 & 0.35 & 1.00 & & & \\
\hline $\begin{array}{l}\text { Stock ownership ratio of } \\
\text { foreign CDP signatories }\end{array}$ & ${ }^{*} 0.83$ & 0.79 & 0.67 & *0.99 & 0.45 & 1.00 & & \\
\hline Risks & 0.77 & 0.66 & 0.43 & *0.84 & 0.16 & *0.86 & 1.00 & \\
\hline Opportunities & 0.78 & 0.72 & 0.38 & * 0.85 & 0.09 & ${ }^{*} 0.86$ & ${ }^{*} 0.99$ & 1.00 \\
\hline
\end{tabular}

*Significant at 5\% level.

rate climate change management and financial results of the corporations. We also found differences in these relationships at the national level that may reflect different business environments and levels of climate change awareness. For Japanese companies, positive correlations between emissions accounting and profitability, and between emissions reduction targeting and profitability, imply that Japanese companies make capital investments that aim to reduce their carbon footprint as well as generate profits. US companies showed some of these same positive correlations except the $\mathrm{CF}$ between climate change management and return on assets which was negative. For UK companies there was a high correlation between a corporation's enterprise valuation and how it sees opportunities for climate change action.

The case study of Japanese automobile manufacturers shows that sales of fuel-efficient vehicles closely correlate with the company's evaluation in financial markets, especially its attractiveness for foreign investors. We also found a relationship between higher sales of the fuelefficient vehicles and how the company addresses climate change risks and opportunities.

Though these results do not prove cause-and-effect, the correlations found suggest plausible relationships between corporate climate change activities and financial performance. Further research is needed to clarify these relationships, which we will do by analyzing different sectors, using longitudinal data and statistical tests for 
causality.

\section{REFERENCES}

[1] F. Takeda and T. Tomozawa, "A Change in Market Responses to the Environmental Management Ranking in Japan," Ecological Economics, Vol. 67, No. 3, 2008, pp. 465-472.

http://dx.doi.org/10.1016/j.ecolecon.2007.12.027
[2] M. Kuribayashi and Y. Kameyama, "Estimation of Influence of Environmental Management Activities and Employment System of Machinery Manufacturers on Their Management," Environmental Information Science, Vol. 24, 2010, pp. 189-194.

[3] Japan Automobile Manufacturers Association, Inc., "Motorcycle Market Trends in Japan in Fiscal 2011," 2012. http://www.jama.or.jp/release/news/attachement/2012040 4_jouyou.pdf 